\title{
Glaciation's topographic control on Holocene erosion at the eastern edge of the Alps
}

\author{
Jean L. Dixon ${ }^{1,2}$, Friedhelm von Blanckenburg ${ }^{1,3}$, Kurt Stüwe ${ }^{4}$, and Marcus Christl ${ }^{5}$ \\ ${ }^{1}$ German Research Centre for Geosciences GFZ, Potsdam, Germany \\ ${ }^{2}$ Department of Earth Sciences and the Institute on Ecosystems, Montana State University, Bozeman, MT, USA \\ ${ }^{3}$ Department of Geosciences, Freie Universität Berlin, Berlin, Germany \\ ${ }^{4}$ Institute of Earth Sciences, University of Graz, Graz, Austria \\ ${ }^{5}$ Laboratory for Ion Beam Physics, ETH Zürich, Zürich, Switzerland \\ Correspondence to: Jean L. Dixon (jean.dixon@montana.edu)
}

Received: 19 May 2016 - Published in Earth Surf. Dynam. Discuss.: 3 June 2016

Revised: 2 November 2016 - Accepted: 12 November 2016 - Published: 22 December 2016

\begin{abstract}
What is the influence of glacial processes in driving erosion and uplift across the European Alps? It has largely been argued that repeated erosion and glaciation sustain isostatic uplift and topography in a decaying orogen. But some parts of the Alps may still be actively uplifting via deep lithospheric processes. We add insight to this debate by isolating the role of post-glacial topographic forcing on erosion rates. To do this, we quantify the topographic signature of past glaciation on millennial-scale erosion rates in previously glaciated and unglaciated catchments at the easternmost edge of the Austrian Alps. Newly measured catchment-wide erosion rates, determined from cosmogenic ${ }^{10} \mathrm{Be}$ in river-borne quartz, correlate with basin relief and mean slope. GISderived slope-elevation and slope-area distributions across catchments provide clear topographic indicators of the degree of glacial preconditioning, which further correlates with erosion rates. Erosion rates in the easternmost, non-glaciated basins range from 40 to $150 \mathrm{~mm} \mathrm{ky}^{-1}$ and likely reflect underlying tectonic forcings in this region, which have previously been attributed to recent (post $5 \mathrm{Ma}$ ) uplift. By contrast, erosion rates in previously glaciated catchments range from 170 to $240 \mathrm{~mm} \mathrm{ky}^{-1}$ and reflect the erosional response to local topographic preconditioning by repeated glaciations. Together, these data suggest that Holocene erosion across the Eastern Alps is strongly shaped by the local topography relict from previous glaciations. Broader, landscape-wide forcings, such as the widely debated deep mantle-driven or isostatically driven uplift, result in lesser controls on both topography and erosion rates in this region. Comparing our data to previously published erosion rates across the Alps, we show that post-glacial erosion rates vary across more than 2 orders of magnitude. This high variation in post-glacial erosion may reflect combined effects of direct tectonic and modern climatic forcings but is strongly overprinted by past glacial climate and its topographic legacy.
\end{abstract}

1

\section{Introduction}

The climatic control on erosion in mountain belts remains a longstanding and active debate in geomorphology. Some of this debate has focused on whether spatial gradients in precipitation can be invoked to drive gradients in erosion or whether these rates are more strongly controlled by their tectonic setting (e.g., Burbank et al., 2003). While some studies have argued for modern precipitation controls on erosion (e.g., Bookhagen et al., 2005), climate's imprints via glacial processes are widely recognized to significantly alter a landscape. For example, abrasion and plucking of bedrock by overlying glacial ice widens and deepens valleys (Brocklehurst and Whipple, 2002). Glacial erosion may increase mountain relief and cause isostatic uplift of rocks (e.g., Champagnac et al., 2007; Molnar and England, 1990). Through an erosional "buzzsaw", glaciers have been suggested to set the limit on mountain range height and relief 
(e.g., Egholm et al., 2009; Mitchell and Humphries, 2015) and accelerate mountain erosion (e.g., Herman et al., 2013). Post-glacially, rivers export unconsolidated sediments stored in basins (Hinderer, 2001; Hoffmann et al., 2007; Wittmann et al., 2016), and steep glacial headwalls and valley sides undergo accelerated hillslope erosion. The resulting postglacial sediments can become effective tools for rivers to rapidly incise their beds (Jansen et al., 2011). Glacial processes significantly alter landscapes and therefore leave a lasting topographic legacy that influences erosion, relief, and possibly uplift tens of thousands of years after glacial retreat (e.g., Salcher et al., 2014). Together, these processes and observations may suggest that glacial forcings are the dominant control on landscape evolution in modern mid- and highlatitude mountain belts.

Notwithstanding the clear topographic and erosional effects that glacial processes imprint in the landscape, there has been notable pushback on the idea that climate via glaciation is the dominant driver of erosion in diverse mountain belts. For example, not all glaciers are efficient eroders, and glaciers frozen to their base may instead protect bedrock from erosion in high topography (Thomson et al., 2010). Even across glacial-interglacial time periods, fluvial incision may outpace glacial erosion in valley bottoms (Montgomery and Korup, 2011). Furthermore, global compilations of erosion rates across multiple temporal scales show similar erosion rates by glaciers and rivers, and these data suggest that tectonics likely controls erosion rates over millennial and longer timescales regardless of glacial history (Koppes and Montgomery, 2009).

This debate regarding climate's influence on mountain belt evolution has been especially active for the European Alps, where both glacial and tectonic forces have been invoked as principle drivers of erosion and uplift (Cederbom et al., 2004; Fox et al., 2015; Mey et al., 2016). Wittmann et al. (2007) and Champagnac et al. (2007) noted that millennial-scale erosion rates vary with - and may exceed - modern uplift rates in the central Alps and that correlations between topography, uplift, and erosion suggest that glacial and postglacial erosion alone may explain rates of uplift in the region via isostasy. Norton et al. (2010a, 2011) further argued that glaciation drives uplift, based on the observation that river knickpoints are highly correlated with previous glacial cover and glacial equilibrium line altitudes. However, it has also been suggested that ongoing collision and active convergence in the Eastern Alps may either primarily drive uplift (Hergarten et al., 2010) or significantly contribute to changes in relief across the Cenozoic (Legrain et al., 2014). In the eastern portion of the range, accelerated rates of river incision and hillslope erosion since $5 \mathrm{Ma}$ have been suggested to record late Tertiary uplift (Legrain et al., 2015; Wagner et al., 2010). These relatively local observations have been coupled with landscape evolution models to suggest that the Alps as a whole are not a decaying orogen as a glacial driver of uplift and erosion may suggest but instead a young mountain range still experiencing tectonic rejuvenation (Hergarten et al., 2010; Robl et al., 2015).

Here, we add insight to the debate on the role of glaciers in driving Holocene Alpine erosion, by quantifying landscape morphology and ${ }^{10} \mathrm{Be}$-derived denudation rates (hereafter called erosion rates) in both unglaciated and previously glaciated basins of the far Eastern Alps. We find that the past glacial history exerts a stronger control on erosion rates across the Eastern Alps than previously invoked tectonic forcings.

\section{Approach}

\subsection{Study site}

Our study region lies in the easternmost region of the European Alps (Fig. 1), composing the Styrian as well as several intramontane basins and adjacent massifs that make up the Alpine uplands: the Lavanttal Alps (including Gleinalpe and Koralpe), the Schladminger Tauern, the Seckauer Tauern, and Pohorje in Slovenia (Fig. 2a). The Styrian Basin (part of the Pannonian Basin) was a shallow marine basin throughout much of the Miocene, becoming brackish and finally freshwater during basin inversion, which commenced around $10 \mathrm{Ma}$ (Bada et al., 2001; Cloetingh et al., 2006). These kilometer-thick Miocene sediments now underlie a gentle hilly terrain that has uplifted some $300 \mathrm{~m}$ above sea level in the last $7 \mathrm{My}$ (e.g., Legrain et al., 2014). The upland regions of adjacent massifs are made up of high-grade metamorphic rocks, with local limestone in the range north of the basin.

Our study region is unique as the only part of the Alps in which unglaciated and formerly glaciated mountainous catchments can be found in immediate proximity. During the glaciation periods of the past million years, only the western portion of the study region was pervasively glaciated (Fig. 1). East of the contiguous Alpine ice cap, only isolated cirque glaciers occurred at elevations above $2000 \mathrm{~m}$, for example in the summit region of the Koralpe range. In unglaciated portions of our study area, previous geomorphic work has recognized two distinct landscape morphologies: a low-gradient, low-relief upland region and a higher-gradient, higher-relief region downstream of river knickpoints (Legrain et al., 2014; Robl et al., 2008). Millennial erosion rates from small basins within these regions correlate with slope and the degree of incision (Legrain et al., 2015). These two morphologies are interpreted as representing the relict and incising portions of a landscape responding to incision initiated at $\sim 4 \mathrm{Ma}$ (Wagner et al., 2010). The timing of incision coincides with the inversion and uplift of the Styrian and northern Molasse basins. No work thus far has compared erosion rates in the previously glaciated and unglaciated portions of this landscape. 


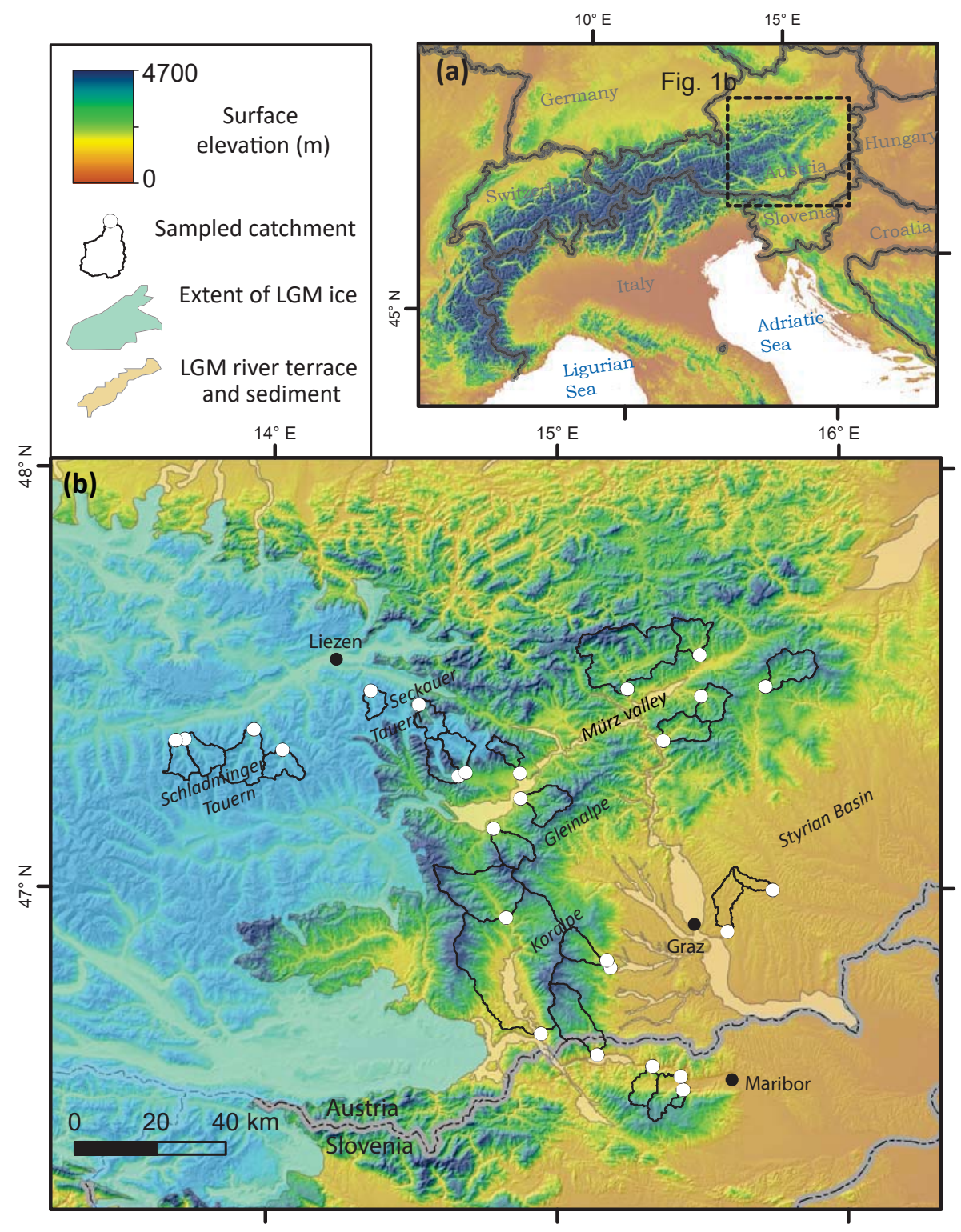

Figure 1. (a) The study area lies in the easternmost region of the European Alps, with sites located across both Austria and northern Slovenia. (b) Catchment outlines and sampling points for our 26 river sand samples, used to measure millennial-scale erosion rates across both previously glaciated and unglaciated catchments. Extent of Last Glacial Maximum (LGM) ice is shown by the blue shaded area. The boundary between the crystalline bedrock of the Alps and the Miocene sedimentary basin (Styrian Basin) follows roughly the 300-500 m elevation contour marked by the yellow color tones.

\subsection{Deriving erosion rates from in situ produced cosmogenic ${ }^{10} \mathrm{Be}$}

Use of the cosmogenic nuclide ${ }^{10} \mathrm{Be}$ in river sand is now standard for quantifying rates of erosion over millennial timescales in diverse landscapes (Granger and Schaller, 2014; Portenga and Bierman, 2011; von Blanckenburg, 2005). Cosmic ray bombardment of Earth's surface produces these nuclides in situ, and their concentrations reflect the time that minerals spend within the upper few meters of Earth's surface. ${ }^{10} \mathrm{Be}$ concentrations in quartz col- lected from river sands reflect erosion rates spatially integrated across the basin. We sampled 26 rivers in the Eastern Alps of Austria and Slovenia for cosmogenic ${ }^{10} \mathrm{Be}$ analysis, targeting both previously glaciated and unglaciated catchments across the region (Tables 1-2). Sand was collected from channel bottoms and active channel bars, integrating along $\sim 20 \mathrm{~m}$ reaches at each river location. Samples were oven-dried and sieved to extract the $250-500 \mu \mathrm{m}$ size fraction. In addition to the $250-500 \mu \mathrm{m}$ fraction, three samples were also sieved at $500-800 \mu \mathrm{m}$, so that we could check for 
Table 1. Data from cosmogenic nuclide analyses.

\begin{tabular}{|c|c|c|c|c|c|c|c|c|c|c|}
\hline Sample & $\begin{array}{r}\text { Size } \\
\text { fraction } \\
(\mu \mathrm{m})\end{array}$ & $\begin{array}{l}\text { Long. } \\
\left({ }^{\circ} \mathrm{E}\right)\end{array}$ & $\begin{array}{l}\text { Lat. } \\
\left({ }^{\circ} \mathrm{N}\right)\end{array}$ & $\begin{array}{r}\text { Sample } \\
\text { elev. }(m)\end{array}$ & $\begin{array}{r}\text { Qtz. } \\
\text { weight } \\
(\mathrm{g})\end{array}$ & $\begin{array}{r}{ }^{10} \text { Be conc. }^{\mathrm{a}} \\
\left(\times 10^{4} \text { atoms }\right. \\
\left.\text { g quartz }^{-1}\right)\end{array}$ & $\begin{array}{r}\text { Snow } \\
\text { shielding } \\
\text { factor }^{\mathrm{b}}\end{array}$ & $\begin{array}{r}\text { Topographic } \\
\text { shielding } \\
\text { factor }^{b}\end{array}$ & $\begin{array}{r}\text { Production rate } \\
\left(\text { atoms } \mathrm{g}_{\text {quartz }}{ }^{-1}\right. \\
\left.\mathrm{yr}^{-1}\right)\end{array}$ & $\begin{array}{r}\text { Denudation rate } \\
\left(\mathrm{mm} \mathrm{ky}^{-1}\right)\end{array}$ \\
\hline Bistrica & $250-500$ & 15.139 & 46.613 & 382 & 30.2 & $10.87 \pm 0.89$ & 0.93 & 0.99 & 9.58 & $69.2 \pm 6.4$ \\
\hline Bistrica & $500-800$ & 15.139 & 46.613 & 382 & 30.2 & $11.74 \pm 0.87$ & 0.93 & 0.99 & 9.58 & $64.0 \pm 5.6$ \\
\hline Feistrichbach & $250-500$ & 14.778 & 47.151 & 717 & 31.2 & $12.79 \pm 0.60$ & 0.92 & 0.98 & 11.63 & $69.3 \pm 4.2$ \\
\hline Gleinbach & $250-800$ & 14.872 & 47.222 & 656 & 33.2 & $9.41 \pm 0.56$ & 0.92 & 0.98 & 10.46 & $86.3 \pm 6.1$ \\
\hline Gleinbach & $500-800$ & 14.872 & 47.222 & 656 & 35.1 & $9.35 \pm 0.45$ & 0.92 & 0.98 & 10.46 & $86.8 \pm 5.0$ \\
\hline Ingering & $250-500$ & 14.680 & 47.285 & 967 & 40.3 & $11.39 \pm 0.56$ & 0.89 & 0.96 & 14.50 & $94.3 \pm 5.8$ \\
\hline Kleinsolk & $250-500$ & 13.938 & 47.382 & 893 & 39.9 & $6.58 \pm 0.57$ & 0.88 & 0.93 & 15.53 & $172.5 \pm 16.2$ \\
\hline Krug & $250-500$ & 14.657 & 47.275 & 938 & 40.2 & $13.81 \pm 0.78$ & 0.90 & 0.97 & 14.24 & $76.5 \pm 5.4$ \\
\hline Lassnitz1 & $250-500$ & 15.184 & 46.820 & 520 & 34.6 & $15.49 \pm 0.62$ & 0.96 & 0.99 & 7.48 & $39.2 \pm 2.1$ \\
\hline Lassnitz3 & $250-500$ & 15.173 & 46.838 & 543 & 31.7 & $13.70 \pm 0.60$ & 0.93 & 0.99 & 9.95 & $56.7 \pm 3.4$ \\
\hline Lavant1 & $250-500$ & 14.824 & 46.939 & 658 & 31.7 & $8.95 \pm 0.58$ & 0.89 & 0.99 & 11.02 & $94.3 \pm 7.0$ \\
\hline Lavant2 & $250-500$ & 14.945 & 46.663 & 370 & 31.5 & $9.95 \pm 0.58$ & 0.94 & 0.99 & 9.81 & $77.4 \pm 5.3$ \\
\hline Mooskogel & $250-500$ & 15.372 & 47.359 & 490 & 39.0 & $7.04 \pm 0.83$ & 0.95 & 0.97 & 9.19 & $103.7 \pm 13.4$ \\
\hline Obertal & $250-500$ & 13.665 & 47.354 & 967 & 40.1 & $5.69 \pm 0.38$ & 0.88 & 0.94 & 15.52 & $199.0 \pm 15.0$ \\
\hline Pickelbach & $250-500$ & 15.750 & 47.003 & 326 & 30.7 & $4.91 \pm 0.38$ & 0.99 & 1.00 & 5.65 & $101.6 \pm 8.3$ \\
\hline Pohorje1 & $250-500$ & 15.434 & 46.529 & 543 & 32.7 & $9.53 \pm 0.78$ & 0.94 & 0.99 & 9.29 & $77.2 \pm 7.1$ \\
\hline Pohorje1 & $500-800$ & 15.434 & 46.529 & 543 & 31.5 & $8.86 \pm 0.47$ & 0.94 & 0.99 & 9.29 & $83.1 \pm 5.1$ \\
\hline Pohorje2 & $250-500$ & 15.425 & 46.560 & 313 & 30.6 & $7.22 \pm 0.50$ & 0.95 & 0.99 & 8.85 & $98.1 \pm 7.7$ \\
\hline Ratten & $250-500$ & 15.732 & 47.487 & 752 & 30.3 & $10.10 \pm 0.48$ & 0.93 & 0.99 & 10.58 & $81.1 \pm 4.8$ \\
\hline Rottenmann & $250-500$ & 14.347 & 47.477 & 1077 & 35.5 & $5.51 \pm 0.39$ & 0.89 & 0.95 & 15.04 & $200.1 \pm 15.9$ \\
\hline SaintNico & $250-500$ & 14.038 & 47.335 & 1053 & 40.0 & $4.88 \pm 0.33$ & 0.88 & 0.95 & 15.93 & $237.5 \pm 17.8$ \\
\hline Seckauer & $250-500$ & 14.871 & 47.283 & 724 & 32.4 & $12.53 \pm 0.70$ & 0.91 & 0.98 & 11.77 & $71.3 \pm 4.8$ \\
\hline Stanz & $250-500$ & 15.506 & 47.465 & 650 & 29.5 & $7.71 \pm 0.65$ & 0.94 & 0.98 & 9.71 & $99.0 \pm 9.3$ \\
\hline Stiefing & $250-500$ & 15.592 & 46.905 & 304 & 31.2 & $4.35 \pm 0.31$ & 0.99 & 1.00 & 5.62 & $114.3 \pm 8.5$ \\
\hline Thörl & $250-500$ & 15.245 & 47.482 & 583 & 40.3 & $6.49 \pm 0.97$ & 0.91 & 0.97 & 9.81 & $118.2 \pm 19.6$ \\
\hline Triebental & $250-500$ & 14.516 & 47.444 & 1063 & 32.2 & $4.50 \pm 0.38$ & 0.90 & 0.96 & 13.95 & $228.7 \pm 21.8$ \\
\hline Untertal & $250-500$ & 13.698 & 47.357 & 999 & 40.5 & $6.53 \pm 0.50$ & 0.88 & 0.93 & 16.00 & $178.1 \pm 15.4$ \\
\hline Veitsch & $250-500$ & 15.502 & 47.564 & 672 & 34.2 & $4.96 \pm 0.51$ & 0.94 & 0.98 & 9.55 & $151.8 \pm 16.5$ \\
\hline Velka & $250-500$ & 15.328 & 46.585 & 372 & 34.3 & $6.91 \pm 0.45$ & 0.96 & 0.99 & 8.13 & $95.8 \pm 6.8$ \\
\hline
\end{tabular}

grain size dependence of ${ }^{10} \mathrm{Be}$ concentrations. Heavy and magnetic minerals were removed using magnetic and density separation methods. Standard hydrochloric and hydrofluoric chemical leaches removed non-quartz minerals and etched weathering rinds from quartz to remove meteoric ${ }^{10} \mathrm{Be}$. We digested $40 \mathrm{~g}$ of clean quartz in a $5: 1$ concentrated hydrofluoric acid : nitric acid mixture, along with $215 \mu \mathrm{mg}$ of an inhouse-developed ${ }^{9} \mathrm{Be}$ carrier derived from phenakite crystal. Beryllium was extracted from digested quartz and oxidized using methods outlined in von Blanckenburg et al. (1996). We measured ${ }^{10} \mathrm{Be} /{ }^{9} \mathrm{Be}$ ratios on $\mathrm{BeO}$ targets with accelerator mass spectrometry at ETH Zürich in Switzerland in June 2010 and 2011. Initial accelerator mass spectrometry (AMS) results are normalized to AMS standard S2007N, with an isotope ratio of $2.81 \times 10^{-11}$. All results are renormalized to the 07KNSTD standardization from Nishiizumi et al. (2007). Table 1 presents analytical results. ${ }^{10} \mathrm{Be}$ concentrations are blank corrected by subtraction (average ${ }^{10} \mathrm{Be} /{ }^{9} \mathrm{Be}$ ratio of five chemical processing blanks $=2.72 \pm 2.21 \times 10^{-15}$ ).

${ }^{10} \mathrm{Be}$ concentrations were used to derive catchment-wide erosion rates, following scaling factors from Dunai (2000), absorption laws for nucleonic interactions from Schaller et al. (2002), and muonic absorption laws from Braucher et al. (2003). We determined basin-averaged production rates using an ArcGIS-based production model, $10 \mathrm{~m}$ gridded elevation data, a sea level, high-latitude total production rate of 4.0 atoms $\mathrm{gqtz}^{-1}$ year $^{-1}$ (Phillips et al., 2016), and assuming that slow and fast muons contribute $\sim 1.2$ and $0.65 \%$ of total production (Braucher et al., 2003). Corrections for skyline shielding were made following Norton and Vanacker (2009). We calculated snow shielding following Norton et al. (2008) using elevation-snow-depth relationships previously determined in the Swiss Alps by Auer (2003). Elevation-snow-depth relationships likely vary spatially and temporally across the Alps; however, these estimates provide the best available constraints on snow shielding. Because our cosmogenic ${ }^{10} \mathrm{Be}$ concentrations only reflect erosion rates in the parts of the basin with quartz-bearing lithologies, parts of drainage basins with carbonate terrains were excluded to calculate integrated basin ${ }^{10} \mathrm{Be}$ production rates (Table 1). ${ }^{10} \mathrm{Be}$-derived erosion rates are presented in Table 2. We compile other ${ }^{10} \mathrm{Be}$-derived erosion rates from 
Table 2. Catchment denudation rates and morphometrics.

\begin{tabular}{|c|c|c|c|c|c|c|c|c|}
\hline Sample & $\begin{array}{r}\text { Glacial } \\
\text { history }^{\mathrm{a}}\end{array}$ & $\begin{array}{l}\text { Catchment } \\
\text { area }\left(\mathrm{km}^{2}\right)\end{array}$ & $\begin{array}{r}\text { Avg. } \\
\text { slope }^{b}\left(^{\circ}\right)\end{array}$ & $\begin{array}{r}\text { Avg. } \\
\text { slope }^{c}\left({ }^{\circ}\right)\end{array}$ & $\begin{array}{r}\text { Mean } \\
\text { elevation } \\
(\mathrm{m})\end{array}$ & $\begin{array}{l}\text { Basin area } \\
>35^{\circ}(\%)\end{array}$ & $\begin{array}{l}\text { Mean local } \\
\text { relief }^{d}(\mathrm{~m})\end{array}$ & $\begin{array}{l}\text { Erosion rate } \\
\left(\mathrm{mm} \mathrm{ky}^{-1}\right)\end{array}$ \\
\hline \multicolumn{9}{|l|}{ Gleinalpe } \\
\hline Feistrichbach & $\mathrm{U}$ & 74.8 & 20.4 & 19.5 & 1322 & $2 \%$ & 1301 & $69.3 \pm 4.2$ \\
\hline Gleinbach & $\mathrm{U}$ & 80.9 & 21.2 & 20.4 & 1243 & $3 \%$ & 1201 & $86.3 \pm 6.1$ \\
\hline \multicolumn{9}{|l|}{ Koralpe } \\
\hline Bistrica & $\mathrm{U}$ & 141.2 & 15.8 & 15.1 & 1181 & $1 \%$ & 1136 & $69.2 \pm 6.4$ \\
\hline Lassnitz1 & $\mathrm{U}$ & 2.9 & 15.6 & 15.5 & 810 & $0 \%$ & 681 & $39.2 \pm 2.1$ \\
\hline Lassnitz3 & $\mathrm{U}$ & 66.3 & 15.5 & 14.8 & 1141 & $0 \%$ & 1155 & $56.7 \pm 3.4$ \\
\hline Lavant1 & $\mathrm{U}$ & 234.5 & 11.6 & 11.4 & 1728 & $0 \%$ & 1450 & $94.3 \pm 7$ \\
\hline Lavant2 & $\mathrm{U}$ & 952.3 & 14.5 & 14.2 & 1029 & $1 \%$ & 1029 & $77.4 \pm 5.3$ \\
\hline \multicolumn{9}{|l|}{ Mürz Valley } \\
\hline Mooskogel & $\mathrm{U}$ & 79.2 & 22.7 & 22.4 & 985 & $6 \%$ & 1017 & $103.7 \pm 13.4$ \\
\hline Ratten & $\mathrm{U}$ & 96.5 & 17.3 & 16.8 & 1213 & $0 \%$ & 1198 & $81.1 \pm 4.8$ \\
\hline Stanz & $\mathrm{U}$ & 62.3 & 19.2 & 19.0 & 1068 & $1 \%$ & 1068 & $99 \pm 9.3$ \\
\hline Thörl & $\mathrm{U}$ & 321.1 & 22.5 & 21.9 & 1166 & $10 \%$ & 1157 & $118.2 \pm 19.6$ \\
\hline Thörl-qtz ${ }^{\mathrm{e}}$ & $\mathrm{U}$ & $(163.7)$ & - & - & - & - & - & $118.2 \pm 19.6$ \\
\hline Veitsch & $\mathrm{U}$ & 73.0 & 20.4 & 20.1 & 1060 & $2 \%$ & 1071 & $151.8 \pm 16.5$ \\
\hline Veitsch-qtz & $\mathrm{U}$ & $(63.3)$ & - & - & - & - & - & $151.8 \pm 16.5$ \\
\hline \multicolumn{9}{|l|}{ Pohorje } \\
\hline Pohorje1 & $\mathrm{U}$ & 10.9 & 15.6 & 14.8 & 1102 & $1 \%$ & 948 & $77.2 \pm 7.1$ \\
\hline Pohorje2 & $\mathrm{U}$ & 78.3 & 15.5 & 14.6 & 890 & $1 \%$ & 897 & $98.1 \pm 7.7$ \\
\hline Velka & $\mathrm{U}$ & 52.5 & 16.4 & 16.0 & 814 & $1 \%$ & 828 & $95.8 \pm 6.8$ \\
\hline \multicolumn{9}{|c|}{ Schladminger Tauern } \\
\hline Kleinsolk & $\mathrm{G}$ & 117.8 & 31.1 & 30.6 & 1742 & $37 \%$ & 1779 & $172.5 \pm 16.2$ \\
\hline Obertal & G & 51.8 & 29.3 & 28.9 & 1800 & $33 \%$ & 1793 & $199 \pm 15$ \\
\hline SaintNico & G & 60.3 & 28.1 & 27.4 & 1792 & $25 \%$ & 1789 & $237.5 \pm 17.8$ \\
\hline Untertal & G & 67.8 & 30.8 & 30.3 & 1834 & $39 \%$ & 1808 & $178.1 \pm 15.4$ \\
\hline \multicolumn{9}{|l|}{ Seckauer Tauern } \\
\hline Ingering & $\mathrm{P}$ & 58.6 & 25.1 & 24.4 & 1679 & $16 \%$ & 1670 & $94.3 \pm 5.8$ \\
\hline Krug & $\mathrm{P}$ & 67.0 & 22.4 & 21.9 & 1606 & $8 \%$ & 1574 & $76.5 \pm 5.4$ \\
\hline Rottenmann & G & 32.2 & 28.0 & 27.2 & 1672 & $25 \%$ & 1654 & $200.1 \pm 15.9$ \\
\hline Seckauer & $\mathrm{P}$ & 37.7 & 21.7 & 21.2 & 1437 & $3 \%$ & 1362 & $71.3 \pm 4.8$ \\
\hline Triebental & G & 54.8 & 24.4 & 23.6 & 1590 & $13 \%$ & 1587 & $228.7 \pm 21.8$ \\
\hline \multicolumn{9}{|l|}{ Styrian Basin } \\
\hline Pickel & $\mathrm{U}$ & 27.7 & 7.5 & 7.0 & 406 & $0 \%$ & 408 & $101.6 \pm 8.3$ \\
\hline Stiefing & $\mathrm{U}$ & 66.6 & 7.7 & 7.2 & 388 & $0 \%$ & 394 & $114.3 \pm 8.5$ \\
\hline
\end{tabular}



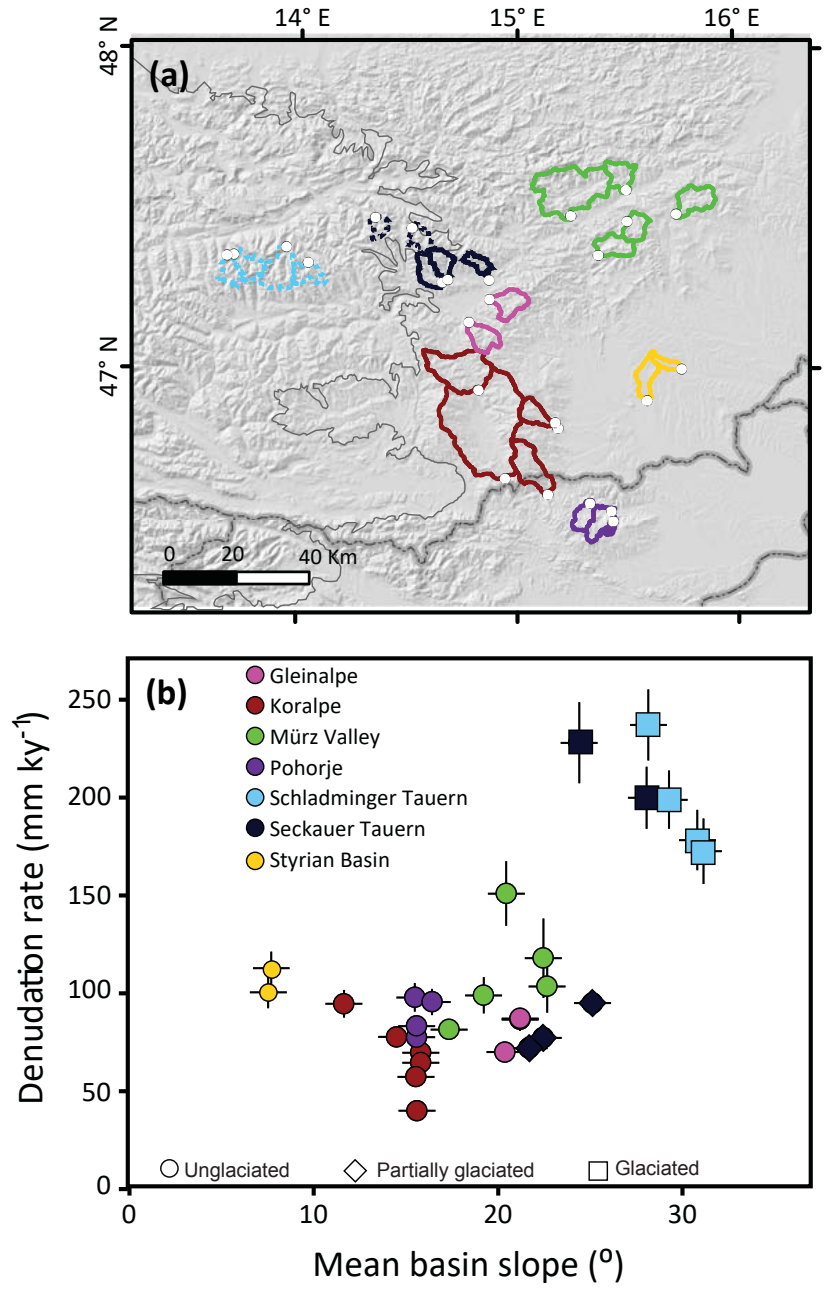

Figure 2. Geographic distribution of erosion rates. (a) Study catchments span several geologic regions marked by distinct massifs and basins. Catchment outlines and data points are color-coded by region. Dashed outlines represent basins that were previously glaciated during the Last Glacial Maximum (LGM). Extent of LGM ice is shown by the thin grey line, and bolder grey lines mark national boundaries. (b) Erosion rates increase with mean basin slope and can generally be grouped by region (replicate samples shown).

across the Alps to gain a regional picture of Holocene erosion. These rates, published in nine different prior studies (Delunel et al., 2010; Glotzbach et al., 2013; Legrain et al., 2015; Norton et al., 2008, 2010b, 2011; Savi et al., 2014; Wittmann et al., 2007, 2016), were derived assuming different sea level, high-latitude (SLHL) production rates. To aid comparison of rates across disparate studies, we recalculate all compiled rates using a consistent SLHL production rate of 4.0 atoms $\mathrm{g}^{-1} \mathrm{yr}^{-1}$, regardless of original scaling factors.

\subsection{Digital terrain analysis}

Catchment topography was analyzed using two digital elevation models: $10 \mathrm{~m}$ gridded data available from the Aus- trian Geological Survey (BEV, http://www.austrianmap.at/) and $3 \operatorname{arcsec}(\sim 80 \mathrm{~m}$ in this region) gridded data from the Global Shuttle Radar Topography Mission (SRTM). Terrain attributes, stream networks, and catchment extents were extracted in ArcGIS on both sets of gridded data. Catchments were delineated upstream of sample points (Table 2). Several catchments lay within Slovenia and outside the extent of the Austrian $10 \mathrm{~m}$ data. Table 2 provides basin-wide terrain attributes, including a comparison of variables extracted from 80 and $10 \mathrm{~m}$ digital elevation models. Though the scale of these digital elevation models (DEMs) is very different, the resulting topographic metrics are quite similar, with only a slight lowering of average slopes in the coarser data. This similarity highlights the fact that local slopes are largely controlled by landscape-scale patterns. If local slopes were variable on a small spatial scale, then analysis of 10 and $80 \mathrm{~m}$ gridded data would likely result in notable differences (e.g., Zhang and Montgomery, 1994).

\section{Results}

${ }^{10} \mathrm{Be}$-derived erosion rates vary from 39 to $238 \mathrm{~mm} \mathrm{ky}^{-1}$ across our study catchments of the Eastern Alps. Catchmentwide erosion rates generally show distinct patterns based on their geographic setting (Fig. 2a, b; Tables 1-2). Rates across Gleinalpe and Koralpe range from 39 to $94 \mathrm{~mm} \mathrm{ky}^{-1}$. The erosion rates measured in catchments entirely within the Styrian Basin (101-114 $\mathrm{mm} \mathrm{ky}^{-1}$; Fig. 1) are notably higher than the rates within the adjacent Koralpe range. Streams in these lowland-basin catchments of the Styrian Basin drain largely unconsolidated sediments of Miocene age that form low-relief hillslopes. Tributaries of the Mürz River valley in the northeast exhibit a broad range in erosion, from 81 to $151 \mathrm{~mm} \mathrm{ky}^{-1}$. Catchment erosion rates in the Schladminger and Seckauer Tauern range from 71 to $238 \mathrm{~mm} \mathrm{ky}^{-1}$. The highest rates in this region $\left(>170 \mathrm{~mm} \mathrm{ky}^{-1}\right)$ correspond to basins that lie within the range of the Last Glacial Maximum ice and reflect the region that was previously glaciated (see Fig. 1). Within the Seckauer Tauern, at the edge of Last Glacial Maximum (LGM) ice, several basins were only partially glaciated (Fig. 2), such that only small portions of the catchment (uppermost elevations) show evidence of glacial impact. Measured erosion rates in these catchments are similar to unglaciated rates in other portions of the study area.

The broad regional differences in basin erosion rates are complemented by relationships between these rates and the topographic form of the basins (Fig. 2a, b). Mean basin slope generally increases with mean elevation (Fig. $3 \mathrm{a} ; r^{2}=0.64$, $p<0.001$ ). This increase in slope is partially controlled by a marked increase in the proportion of slopes that are steeper than $35^{\circ}$ at high elevations (Fig. 3a). Measured erosion rates also generally increase with increasing mean basin slope (Fig. $2 \mathrm{~b} ; r^{2}=0.58, p<0.001$ ). These correlations persist across catchments of disparate drainage areas (Fig. 3b). 

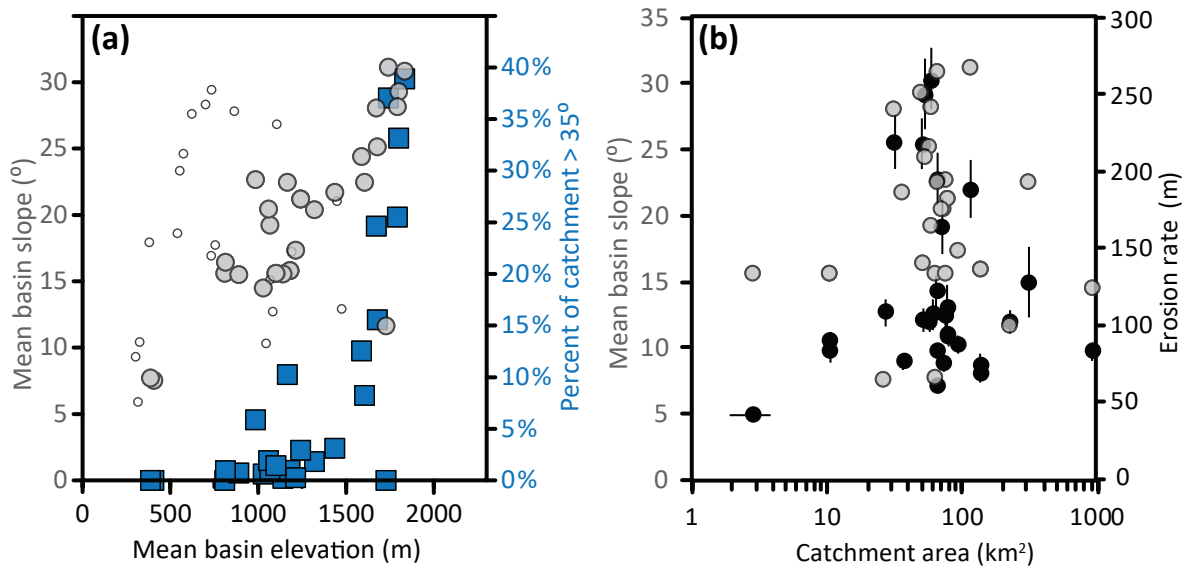

Figure 3. (a) Study catchments show increasing mean slope with mean elevation (grey circles). The percent of slopes $>35^{\circ}$ within these basins increase nonlinearly with elevation (blue squares), such that catchments at high elevations $>1500 \mathrm{~m}$ show strong variation in the distribution of steep, threshold-style hillslopes. Small unglaciated basins studied by Legrain et al. (2015) in this same region show little systematic variation in slope with elevation (small open circles). Instead of reflecting the broader regional signal, mean slopes of these smaller basins are likely controlled by their position with respect to river knickpoints and the proportion of the catchment that is actively incising. (b) Catchments sampled in this study range from $\sim 3$ to $950 \mathrm{~km}^{2}$ (Table 2). Catchment size appears to have limited systematic influence on mean basin slope and measured erosion rates, since basins of similar size show significant variation in both.

Catchments in the Schladminger Tauern and northern parts of the Seckauer Tauern were glaciated in the Pleistocene (Fig. 2a). These catchments exhibit the most rapid erosion rates across the study area (Fig. 4a; $170-230 \mathrm{~mm} \mathrm{ky}^{-1}$ ), and have higher average slopes than non-glaciated and only partly glaciated basins (Fig. 4b-d). Hillslope gradients of unglaciated and partially glaciated basins tend to be normally distributed about mean and modal slopes that range widely from $\sim 5$ to $25^{\circ}$ (Fig. $4 \mathrm{c}$ ). In comparison, previously glaciated basins show higher mean and modal slopes $>25^{\circ}$ with a negative skew towards low values. Furthermore, we find that these two domains also show clear distributions of slope with elevation. By segmenting each catchment into distinct elevation bins between $50 \mathrm{~m}$ contours, we determined the relationship between mean slope angle and mean elevation within the bins (Fig. 5). Dissimilar patterns emerge in how slope varies with elevation within previously glaciated and non-glaciated catchments. For example, high-gradient hillslopes within the non-glaciated basins tend to occur at the upper portions of these basins, well above the mean elevation. However, the steepest hillslopes of glacially sculpted basins are found at elevations well below the mean $(<1500 \mathrm{~m}$ elevation compared to average elevations of $\sim 1800 \mathrm{~m}$ ).

\section{Discussion}

\subsection{Topographic controls on erosion rates}

Correlations between ${ }^{10} \mathrm{Be}$-derived erosion rates and mean catchment slope (Fig. 2b) are consistent with trends previously observed across other diverse mountain ranges (e.g.,
Cyr et al., 2010; Ouimet et al., 2009), such that erosion rates increase nonlinearly with mean catchment slope. This nonlinear relationship may result either from the dominance of threshold-driven landsliding in controlling erosion across the range (e.g., Montgomery and Dietrich, 1994) or from nonlinear diffusive transport (Roering et al., 2001). Either of these erosional mechanisms may result in a similar form to the nonlinear relationships between erosion rates and slope (e.g., DiBiase et al., 2010). Considering that both erosion rates and catchment mean slope correlate with the proportion of the catchment that exceeds $35^{\circ}$ (Fig. 2b) and that these steep slopes generally are void of soil cover, it is likely that local slopes $>35^{\circ}$ within catchments undergoing erosion rates of $\sim 200 \mathrm{~mm} \mathrm{ky}^{-1}$ correspond to thresholds for soil cover in this landscape.

Though we find a general trend of increasing erosion rates with basin slope, this pattern is largely shown by two unique clusters of data: unglaciated basins that exhibit low erosion rates and low to moderate slopes and previously glaciated basins with high slopes and erosion rates. Within each of these domains, the erosion-rate-slope relationships are less clear. Furthermore, it is surprising that several basins at the lowest elevations in the Styrian Basin to the south erode at faster rates than catchments in the middle uplands of the Koralpe range (Figs. 2, 4). These slightly higher erosion rates at low elevation have previously been linked to both weaker lithologies and tectonic transience in the Koralpe range, such that a wave of incision and erosion propagating upslope has accelerated erosion but not yet reached upper relict landscapes. Legrain et al. (2015) mapped the transition between incising and upland relict hillslopes and found that erosion rates in small basins $\left(<1 \mathrm{~km}^{2}\right)$ across Koralpe correlate with 

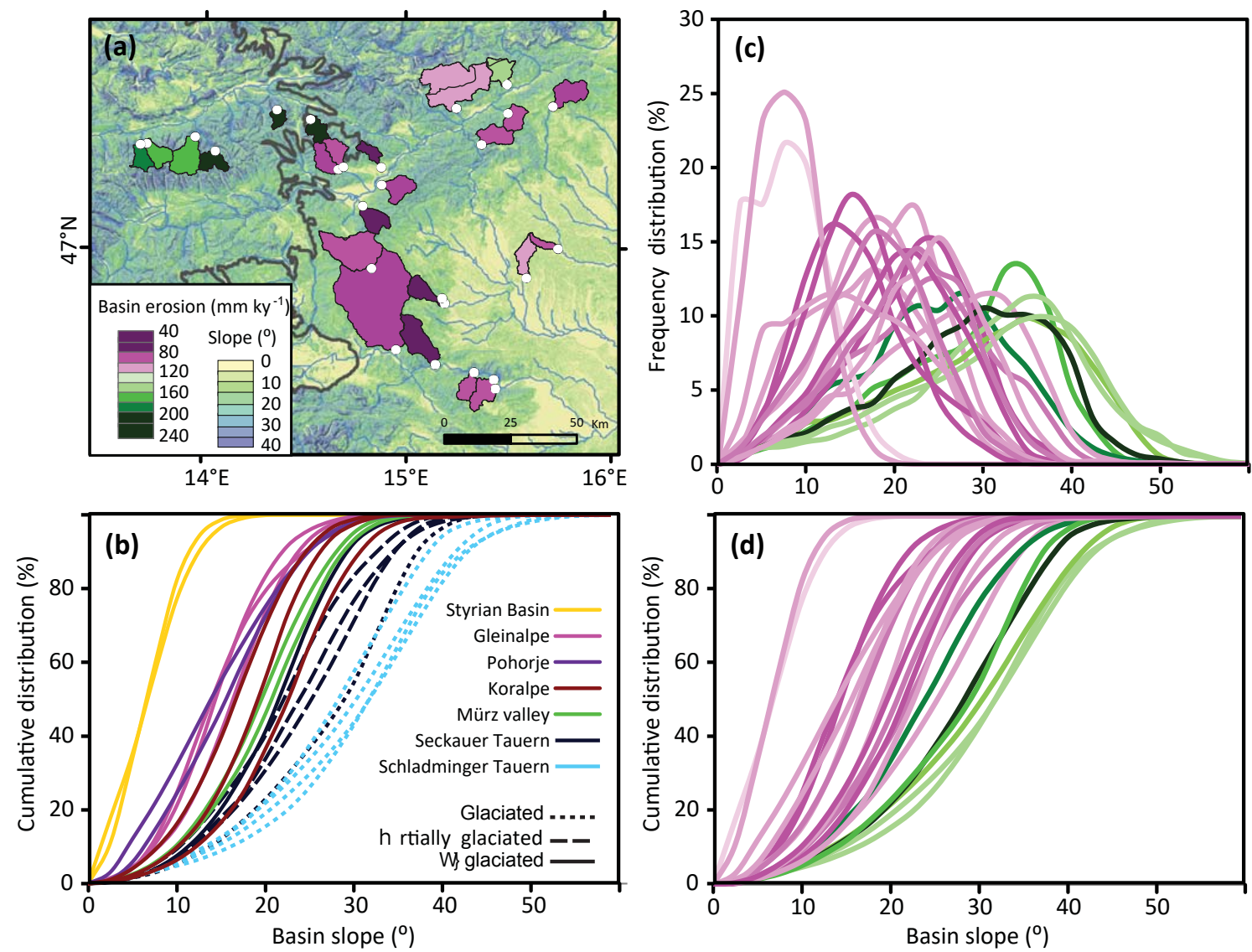

Figure 4. (a) Map of sampled basins across the Eastern Alps, color-coded for erosion rates. (b) Cumulative slope distributions color-coded by sample region (same as Fig. 2) show that catchment morphology follows geographic groupings, with low-slope end-members in the Styrian Basin and high-slope end-members represented by previously glaciated basins of the Schladminger and Seckauer Tauern (dotted lines). Slope distributions across these basins also complement measured erosion rates. (c, d) Frequency and cumulative distributions of basin slope show that rapidly eroding, previously glaciated basins tend to have higher mean and modal slopes than more slowly eroding basins. Colors in panels (c) and (d) correspond to the scale for basin erosion shown in panel (a).

the fraction of the catchment below transient propagating knickpoints. Catchment morphology and erosion rates within these small basins show greater variability at mid-to-low elevations than the larger basins studies here, and reflect the local topographic and erosional response of hillslopes to transient river incision (Legrain et al., 2014; Robl et al., 2008). Higher rates in the Styrian Basin compared to the uplands of Koralpe therefore likely reflect this erosional response to river incision and tectonic processes across the range rather than lithologic differences. This local-scale topographic variability and transience attributed to tectonics is likely only reflected in the high rates in the Styrian Basin and is not otherwise strongly reflected in the large basins studied in this paper, which we believe integrate spatially across this variability.

\subsection{Glacial legacies and their influence on Holocene erosion in the Eastern Alps}

We hypothesize that topography-erosion relationships reflect the control of glacial legacies on mountain erosion in this Alpine system. Indeed, we find that the fastest eroding catchments were previously eroded in the Pleistocene and have higher averaged slopes than unglaciated ones (Fig. 2). However, basin average slope angles only provide limited proof of concept since we find a wide range of mean values across both unglaciated and glaciated basins. The distribution of slopes within each catchment provides an added topographic fingerprint of past glaciation (Fig. 3). Mean slopes tend to be greater at low elevations than high elevations in the faster eroding, glacially sculpted catchments. This detailed distribution of slope and elevation within glaciated basins is not distinct from the general trend of increasing mean basin slope with mean basin elevation across the study area (Fig. 3a). The distribution of slope by elevation within 


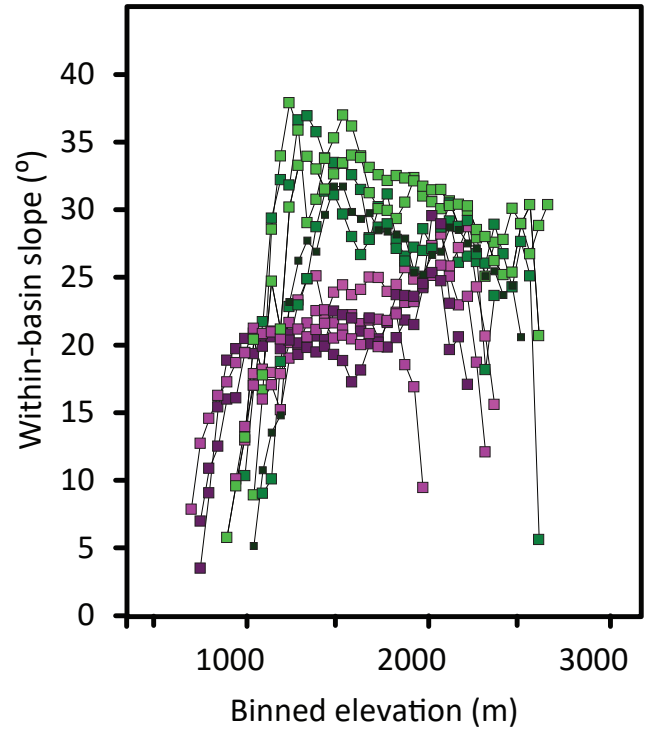

Figure 5. Variation of slope and elevation within sample catchments. Elevation is binned between $50 \mathrm{~m}$ contours, and catchment slopes are averaged within these bins. Hillslope angles are distinctly distributed with basin elevation between slow and rapidly eroding catchments, with highest slope angles found at middle elevations of previously glaciated basins and highest elevations of non-glaciated basins. Symbol colors correspond to the scale for basin erosion shown in Fig. 4a.

basins (Fig. 5) therefore represents a local signal not reflective of the larger regional trend, and we consider it a fingerprint of past glacial sculpting, consistent with characteristic slope-elevation curves and relief in glacial and nonglacial catchments (Robl et al., 2015; van der Beek and Bourbon, 2008). Considering that these previously glaciated basins erode at rates roughly 3 times faster than average nonglaciated basins, this slope distribution similarly provides a predictive tool for erosion rates (Fig. 5).

Importantly, past glaciation may have other impacts on measured erosion rates that must also be considered. ${ }^{10} \mathrm{Be}-$ derived rates presented in this study are calculated assuming erosion has been constant for sufficient time for the landscape surface to attain steady-state ${ }^{10} \mathrm{Be}$ concentrations. This assumption may not be correct when erosion rates have been variable over the integration time of ${ }^{10} \mathrm{Be}$ accumulation or if the surface has been zeroed by deep erosion, as is likely the case for previously glaciated areas. Furthermore, this assumption may result in nontrivial overestimation in calculated erosion rates, especially in slowly eroding terrain (Glotzbach et al., 2013; Norton et al., 2010b; Wittmann et al., 2007). Using non-steady-state calculations from Lal (1991) and assuming that ${ }^{10} \mathrm{Be}$ concentrations at the surface began to accumulate only after deglaciation at $15 \mathrm{ka}$ would result in as much as a $9 \%$ difference in calculated erosion rates from the steady-state rates presented in Table 1 (based on steadystate erosion rates for glaciated basins of $172-203 \mathrm{~mm} \mathrm{ky}^{-1}$ ).
This steady-state assumption therefore results in a nontrivial but still relatively small bias to calculated erosion rates, considering that our glaciated basins erode roughly a factor-of-2 times faster than non-glaciated basins and up to a factor-of-5 times faster than background erosion rates near $40 \mathrm{~mm} \mathrm{ky}^{-1}$.

Another complication of measuring ${ }^{10} \mathrm{Be}$-derived denudation rates in complex previously glaciated terrain results from the potential that glacial erosion products, potentially remobilized from storage in moraines or flood plains, will have inherited ${ }^{10} \mathrm{Be}$ concentrations associated with preglacial times. This may occur if glaciers have incompletely zeroed surface concentrations via shallow erosion (Delunel et al., 2014) or if glacial advance overrode soils and later incorporated them into glacially eroded sediments (Wittmann et al., 2007). In this case, ${ }^{10} \mathrm{Be}$ concentrations may instead underestimate erosion rates, though this effect should be the largest in currently glaciated or recently glaciated catchments. A final complication may arise due to the fact that previously glaciated catchments may contain high-altitude, lowgradient areas such as cirque valleys. If these portions of the landscape did not deliver sediment, perhaps because it was trapped in cirque lakes, then they should be excluded from calculated production rates. Hence catchment-wide production rates would decrease and so would denudation rates. This could result in erosion rates in glacially conditioned catchments being lower than calculated.

\subsection{Competing controls on Holocene erosion rates}

We find compelling evidence of topographic control on erosion; however, other competing hypotheses may explain some of the range of erosion rates found across the region. For example, other climatic controls such as precipitation rates have been invoked to explain fast erosion rates in high peaks of the Alps (Anders et al., 2010). In the Western and Italian Alps, several lines of evidence were used to suggest that post-glacial climates drive the bulk of exhumation and erosion in the region. Multiple studies have suggested that temperature-driven frost-cracking processes likely control Holocene erosion rates, based on correlations between elevation and erosion rates (Delunel et al., 2010; Savi et al., 2015). It might be hypothesized that the intensity of frost-cracking processes is (or was) greatest in our previously glaciated catchments, thus potentially explaining the distribution of erosion rates. Across our study basins, catchment mean slope and elevation are correlated (Fig. 3a); however, elevation poorly correlates with the fraction of steep $\left(>35^{\circ}\right)$ slopes, notably in the rapidly eroding, previously glaciated basins where the abundance of steep topography varies widely despite similar mean basin elevations. Therefore, the elevational proxy for frost cracking does not correspond to topographic indicators of rapid erosion in our study area. Furthermore, we find large differences in erosion rates in basins of the same elevation (Table 2). While frost cracking may enhance erosion at Alpine sites, it does not appear 
to explain the patterns and variability in erosion rates across our catchments. Furthermore, mean annual precipitation is likely a poor indicator of erosion in our unglaciated catchments since areas of the Mürz Valley that display the highest non-glacial erosion rates tend to be drier than more slowly eroding portions of the Koralpe range (BMLFUW, 2007).

Our measured hillslope erosion rates in the Eastern Alps may also be driven by rock uplift and river incision across the region. Previous work has suggested that glaciation during the LGM may drive a Holocene erosional response across the Alps and thereby enhance uplift (Wittmann et al., 2007). Providing a mechanism to engineer this link, Norton et al. (2010a) used observations of correlated river knickpoints and LGM equilibrium line altitudes (ELAs) to suggest that the topographic imprint of glacial erosion leads to increased river incision post-glacially, which in turn strengthens the positive feedback between rock uplift and erosion. Could this same mechanism be invoked to explain high erosion rates in our previously glaciated catchments? If catchment erosion were driven by increased river incision, then we would expect steeper stream gradients in rapidly eroding catchments. Legrain et al. (2015) observed correlations between higher normalized stream steepness indices and erosion rates within the Koralpe region of our study area but only within small non-glaciated catchments. Therefore, evidence of incisiondriven hillslope erosion was found only in the absence of glacial forcings. This finding led Legrain et al. (2015) to suggest that tectonic uplift in the Eastern Austrian Alps could reasonably explain both $500 \mathrm{~m}$ of relief change and a factorof-3 spatial variation in Holocene erosion rates. The scale of uplift (encompassing both the Pannonian Basin and entire eastern end of the Alps) may reflect deep-seated lithospheric processes (Legrain et al., 2015), and seismic anisotropy suggests slab detachment could provide the tectonic mechanism for surface uplift in this Eastern region (Qorbani et al., 2015).

Erosional response to rock uplift may explain local erosional differences within the non-glaciated catchments studied here. For example, following Legrain's model, lowelevation catchments in the Styrian Basin lie within the incised region below river knickpoints, while higher-elevation catchments in Koralpe with lower erosion rates include significant portions of "relict terrain". Importantly, this surface uplift mechanism cannot similarly account for erosional differences between glaciated and non-glaciated basins. The glaciated basins studied here would fall within the "relict landscape" region mapped by Legrain et al. (2015) as above river knickpoints, and therefore our high erosion rates do not correlate with the area below knickpoints. Furthermore, if uplift drove erosion in these basins, then we would expect to see higher area-normalized stream gradients in more rapidly eroding catchments reflecting the enhanced river incisional response. Figure 6 shows local hillslope gradients within each catchment, binned by accumulation area, the upslope and upstream contributing area for all points within the basin. While mean basin slopes are generally higher in more

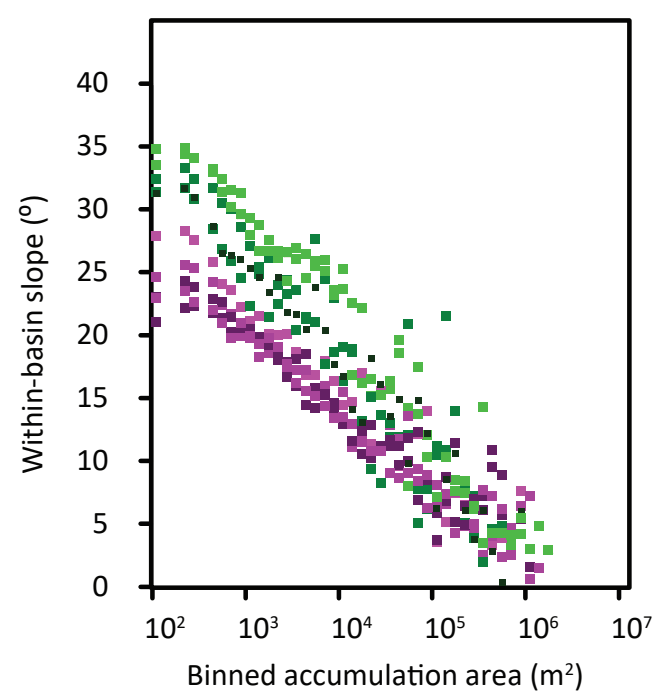

Figure 6. Slope-area plots for catchments across the study area. Accumulation area is calculated on a per pixel basis from the $10 \mathrm{~m}$ digital elevation model and represents the upslope contributing area (drainage area). Slopes within each catchment are binned by increments of $0.2 \log _{10}$ accumulation areas to show downslope and downstream changes in mean basin gradient. Binned values are color-coded by erosion rate and correspond to the basin erosion scale provided in Fig. 4a. Data points in large accumulation areas $\left(>10^{5} \mathrm{~m}^{2}\right)$ reflect local stream steepness and plot within a similar range of values despite disparate erosion rates. However, data points in small accumulation areas $\left(<10^{4} \mathrm{~m}^{2}\right)$ represent upslope hillslope gradients and have distinct steepnesses based on the erosion rates of the basin and the glacial history. These data largely reflect disparate hillslope steepnesses between glaciated (rapidly eroding; green) and unglaciated (more slowly eroding; pink) catchments.

rapidly eroding glaciated catchments, these higher gradients occur only at the uppermost portions of the catchments in small upslope accumulation areas less than $\sim 10^{2} \mathrm{~m}^{2}$ that are within the hillslope domain. By comparison, local stream gradients in glaciated and non-glaciated basins are similar in the larger contribution areas (approaching $10^{5} \mathrm{~m}^{2}$ ) that reflect the fluvial domain. The variability in within-basin slope seen only in low contributing areas indicates that the morphological differences within our large catchments studied here are driven by processes solely within the hillslope domain. The lack of evidence of incision-driven erosion further supports our conclusions that topographic forcings, and not rock uplift, are largely responsible for the patterns in erosion we observe here.

\subsection{Erosion and topography across the Alpine range}

While post-glacial topography largely explains the range of erosion rates found at the far end of the Eastern Alps, we note that these measured erosion rates are still significantly lower than measurements across other regions of the Alps (Fig. 7a). The highest rates measured in our study region are amongst 

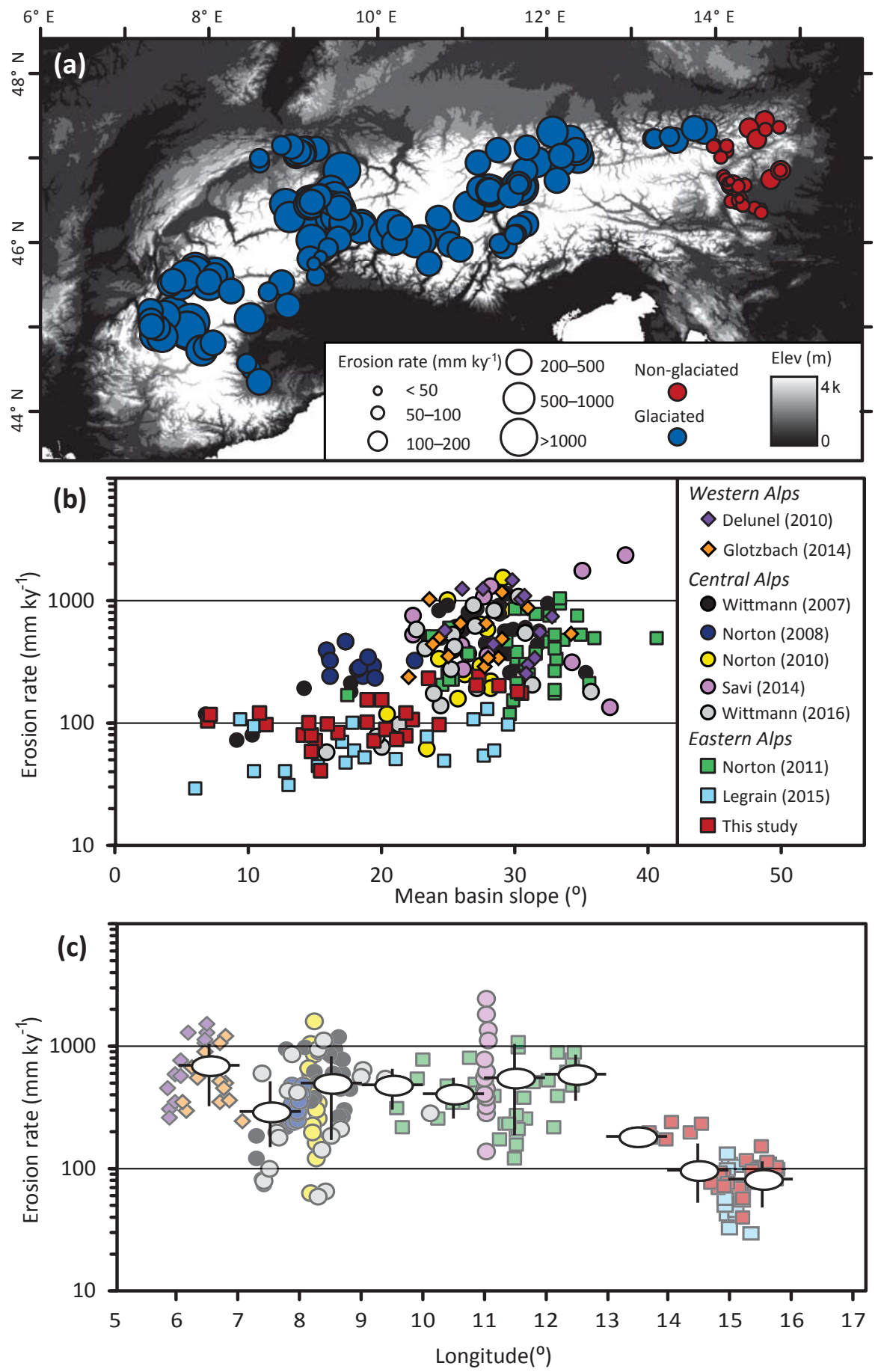

Figure 7. (a) Published erosion rates across the European Alps range from $\sim 40$ to $2100 \mathrm{~mm} \mathrm{ky}^{-1}$, recorded by over 100 cosmogenic samples from nine studies that report both mean catchment slope and erosion rates. Published erosion rates were rescaled to a consistent sea level, high-latitude production rate of 4.0 atoms $\mathrm{g}^{-1}$ year $^{-1}$. Symbol size reflects erosion rate, and symbol color reflects past glacial history (red: previously unglaciated; blue: previously glaciated). (b) Across the range, these rates vary only weakly but significantly with mean basin slope (linear fit $r^{2}=0.23$; exponential fit $r^{2}=0.34$ ). (c) Compiled erosion rates plotted against sample longitude (data provided in the Supplement). Symbols for individual samples are color-coded as in panel (b) but with slight transparency so as to increase visibility of average erosion rates binned by $1^{\circ}$ latitude (grey ovals). The $y$ axis error bars reflect standard deviation (standard error is smaller than symbols). Despite variations in surface uplift, precipitation, and other potential controlling variables, we find little systematic east-to-west variation in average Holocene erosion rates across the range. Only rates in our easternmost study region appear to vary significantly from other portions of the Alpine range. 
the lowest measured across the Alpine range. Compiling previously reported cosmogenic ${ }^{10} \mathrm{Be}$-derived rates across the Alps, we find that mean basin slope and Holocene erosion rates are generally weakly correlated (linear regression $r^{2}=$ $0.26, p<0.001$ ), providing limited predictive power for assessing erosion patterns (Fig. 7b) on an orogen scale. A lack of correlation is not surprising at high mean slope angles and rapid erosion rates since erosional processes become nonlinear approaching threshold slope angles (e.g., DiBiase et al., 2010). Poor correlations between most topographic metrics and Alpine erosion rates have been noted before (e.g., Norton et al., 2011; Salcher et al., 2014; Wittmann et al., 2007). Complexities in lithologic variation can partially explain the high scatter in erosion rates at steep gradients (e.g., Norton et al., 2011) since rock strength and fracturing may control slope thresholds. Weaker lithologies often correspond to low hillslope gradients (e.g., Norton et al., 2011) and normalized stream steepness indices (Sternai et al., 2012) in the absence of other controls. Despite some lithologic influence, orogenscale controls on Holocene denudation rates have remained relatively elusive.

We might expect Holocene erosion to reflect uplift or rates of long-term exhumation across the range. In the central Alps, some of the observable modern rock uplift has been attributed to a combination of an isostatic response to Holocene erosion (Champagnac et al., 2007; Wittmann et al., 2007) and ice melting (Barletta et al., 2006). Though some dispute this latter mechanism as a driver of modern rock uplift (e.g., Persaud and Pfiffner, 2004), recent flexural models based on glacial ice thickness suggest that glacial isostatic adjustment primarily explains the magnitude and patterns of modern uplift (Mey et al., 2016). Long-term exhumation rates from thermochronometric ages have been partially attributed to deep tectonic processes that increased during the Cenozoic (Cederbom et al., 2011), possibly due to slab detachment focused primarily in the west (Baran et al., 2014; Fox et al., 2014, 2015) but also potentially observable in the Eastern Alps (Qorbani et al., 2015). Short-term rates of uplift and erosion and modern topographic metrics appear to poorly or only partially reflect this broad tectonic signal (Koons, 2009; Norton et al., 2011; Vernon et al., 2009), though alongorogen tectonic differences cannot be ruled out as contributing to the variation in erosion rates (Baran et al., 2014). However, on an orogen scale and with the exception of the far Eastern Alps where erosion rates are low, average erosion rates vary little with longitude across the range despite high local variability (Fig. 7c).

Climate variability should also be considered in controlling erosion on an orogen scale. Precipitation patterns vary across the range, with highest LGM precipitation occurring on the northern slopes of the Alps and decreasing to the south and east (Florineth and Schlüchter, 2000). Modern precipitation varies from $\sim 400$ to $>3000 \mathrm{~mm} \mathrm{yr}^{-1}$ across the orogen, also generally decreasing to the east, and small-scale variations in topography have a pronounced effect on lo- cal patterns (Isotta et al., 2014). This means that precipitation varies on both large and small scales across the orogen. There is reason to believe that modern precipitation gradients should control Holocene erosion and sediment transport by influencing the discharge of sediment out of a basin, controlling landslide thresholds, and by influencing the magnitude of river incision. While similar relationships have been observed across other mountain ranges (e.g., Bookhagen et al., 2005), explicit links between modern precipitation and postglacial hillslope erosion remain elusive in the Alps (Bennett et al., 2013; Schlunegger and Norton, 2013). However, multiple lines of evidence, including data presented here, suggest that paleoclimate may instead have a greater and lasting imprint on landscape topography and erosion. Anders et al. (2010) found that precipitation is inversely correlated with the elevation of cirque floors in portions of the Swiss Alps, suggesting a climate-driven glacial buzzsaw across the region. Furthermore, glacial erosion during the Pleistocene resulted in notable increases in valley-scale topographic relief (Sternai et al., 2012; Valla et al., 2011). Because these glacially driven topographic legacies persist to the modern day, we propose that modern hillslope response to glacial history can partly explain local-scale variability in erosion rates. Though focused locally in the Eastern Alps, our new erosion rates and topographic analysis add weight to an increasingly compelling argument that local Holocene denudation rates across the Alps, which often poorly reflect other broader tectonic and climatic controls, are overprinted by the local topographic legacy of glacial sculpting. It is not yet clear whether the topographic legacy and its influence on Holocene erosion directly reflects the local magnitude of past glaciation (e.g., LGM ice thickness) or perhaps whether erosional and morphometric variability in previously glaciated portions of the Western and central Alps is especially variable since modern hillslope response to deglaciation may be considered transient.

\section{Conclusions}

Our study provides multiple lines of evidence that Holocene erosion in the Eastern Austrian Alps is driven by glacial legacies that set local topographic forcing and hillslope morphology. Previous work in the region established that deep-seated tectonic processes could explain almost a factor-of-3 variation in erosion rates in unglaciated terrain $\left(49-137 \mathrm{~mm} \mathrm{ky}^{-1}\right.$; Legrain et al., 2015). Post-glacial topographic forcings account for an additional doubling over invoked tectonic forcings (resulting in erosion rates averaging $200 \mathrm{~mm} \mathrm{ky}^{-1}$ and up to $\sim 240 \mathrm{~mm} \mathrm{ky}^{-1}$ in previously glaciated basins). Considering that glaciers occupied uplands which are not yet reached by river knickpoints, this glacial forcing is far in excess of background erosion rates inferred to be pre-Miocene (49 $\mathrm{mm} \mathrm{ky}^{-1}$; Legrain et al., 2015). Therefore, despite evidence of young uplift across the eastern extent of the range, 
glacial processes still dominate the erosion signal, with deeper tectonic forcings likely observable only in the absence of strong local topographic forcings. Our new data suggest that post-glacial topographic forcing can account for a 4-5fold increase over background hillslope erosion rates in the absence of tectonic forcings. Comparison with erosion rates across the Alpine range shows that these glacially enhanced rates are still among the lowest measured across the Alpine orogen and that combined complexities in tectonic forcings (e.g., Wagner et al., 2010), modern and past climatic forcings (e.g., Anders et al., 2010), and transient erosional response to inherited topographic legacies (this study) must all be considered to understand controls on Alpine Holocene erosion.

\section{Data availability}

Tables in this paper provide raw data, and the supplement accessible here provides all compiled data used from other sources.

\section{The Supplement related to this article is available online at doi:10.5194/esurf-4-895-2016-supplement.}

Acknowledgements. This work was funded by the Topo-Alps Project (German National Science Foundation DFG grant BL562/8 to FvB). Jean L. Dixon acknowledges support from a Montana Institute on Ecosystems award from NSF EPSCoR EPS-1101342. The authors thank Nicolas Legrain for contributions in the field and lab and Hella Wittmann for laboratory support. The authors wish to thank Peter van der Beek and Pierre Valla for their insightful reviews.

The article processing charges for this open-access publication were covered by a Research

Centre of the Helmholtz Association.

Edited by: J. Braun

Reviewed by: P. A. van der Beek and P. Valla

\section{References}

Anders, A. M., Mitchell, S. G., and Tomkin, J. H.: Cirques, peaks, and precipitation patterns in the Swiss Alps: Connections among climate, glacial erosion, and topography, Geology, 38, 239-242, 2010.

Auer, M.: Regionalisierung von Schneeparametern - Eine Methode zur Darstellung von Schneeparametern im Relief, University of Bern, Unpublished Masters Thesis, 97 pp., 2003.

Bada, G., Horváth, F., Cloetingh, S., Coblentz, D. D., and Tóth, T.: Role of topography-induced gravitational stresses in basin inversion; the case study of the Pannonian Basin, Tectonics, 20, 343-363, 2001.
Baran, R., Friedrich, A. M., and Schlunegger, F.: The late Miocene to Holocene erosion pattern of the Alpine foreland basin reflects Eurasian slab unloading beneath the western Alps rather than global climate change, Lithosphere, 6, 124-131, 2014.

Barletta, V., Ferrari, C., Diolaiuti, G., Carnielli, T., Sabadini, R., and Smiraglia, C.: Glacier shrinkage and modeled uplift of the Alps, Geophys. Res. Lett., 33, L14307, doi:10.1029/2006GL026490, 2006.

Bennett, G. L., Molnar, P., McArdell, B. W., Schlunegger, F., and Burlando, P.: Patterns and controls of sediment production, transfer and yield in the Illgraben, Geomorphology, 188, 68-82, 2013.

BMLFUW: Hydrological atlas of Austria, Federal Ministry of Agriculture, Forestry, Environment and Water Management, Vienna, 2007.

Bookhagen, B., Thiede, R. C., and Strecker, M. R.: Late Quaternary intensified monsoon phases control landscape evolution in the northwest Himalaya, Geology, 33, 149-152, 2005.

Braucher, R., Brown, E. T., Bourlès, D. L., and Colin, F.: In situ produced $10 \mathrm{Be}$ measurements at great depths: implications for production rates by fast muons, Earth Planet. Sc. Lett., 211, 251258, 2003.

Brocklehurst, S. H. and Whipple, K. X.: Glacial erosion and relief production in the Eastern Sierra Nevada, California, Geomorphology, 42, 1-24, 2002.

Burbank, D. W., Blythe, A. E., Putkonen, J., Pratt-Sitaula, B., Gabet, E., Oskin, M., Barros, A., and Ojha, T. P.: Decoupling of erosion and precipitation in the Himalayas, Nature, 426, 652-655, 2003.

Cederbom, C. E., Sinclair, H. D., Schlunegger, F., and Rahn, M. K.: Climate-induced rebound and exhumation of the European Alps, Geology, 32, 709-712, 2004.

Cederbom, C. E., van der Beek, P., Schlunegger, F., Sinclair, H. D. and Oncken, O.: Rapid extensive erosion of the North Alpine foreland basin at 5-4 Ma, Basin Res., 23, 528-550, 2011.

Champagnac, J., Molnar, P., Anderson, R., Sue, C., and Delacou, B.: Quaternary erosion-induced isostatic rebound in the western Alps, Geology, 35, 195-198, 2007.

Cloetingh, S., Bada, G., Mapenco, L., Lankreijer, A., Horváth, F., and Dinu, C.: Neotectonics of the Pannonian-Carpathian system: Inferences from thermo-mechanical modelling, in: European Lithosphere Dynamics, edited by: Gee, D. G. and Stephenson, R. A., Geological Society of London Memoir, 32, 207-221, 2006.

Cyr, A. J., Granger, D. E., Olivetti, V., and Molin, P.: Quantifying rock uplift rates using channel steepness and cosmogenic nuclide-determined erosion rates: Examples from northern and southern Italy, Lithosphere, 2, 188-198, 2010.

Delunel, R., van der Beek, P. A., Carcaillet, J., Bourlès, D. L., and Valla, P. G.: Frost-cracking control on catchment denudation rates: Insights from in situ produced ${ }^{10} \mathrm{Be}$ in stream sediments (Ecrins-Pelvoux massif, French Western Alps), Earth Planet. Sc. Lett., 293, 72-83, 2010.

Delunel, R., van der Beek, P. A., Bourlès, D. L., Carcaillet, J., and Schlunegger, F.: Transient sediment supply in a high-altitude Alpine environment evidenced through a ${ }^{10} \mathrm{Be}$ budget of the Etages catchment (French Western Alps), Earth Surf. Proc. Land., 39, 890-899, 2014.

DiBiase, R. A., Whipple, K. X., Heimsath, A. M., and Ouimet, W. B.: Landscape form and millennial erosion rates in the San 
Gabriel Mountains, CA, Earth Planet. Sc. Lett., 289, 134-144, 2010.

Dunai, T. J.: Scaling factors for production rates of in situ produced cosmogenic nuclides: a critical reevaluation, Earth Planet. Sc. Lett., 176, 157-169, 2000.

Egholm, D. L., Nielsen, S. B., Pederson, V., K., and Lesemann, J., E.: Glacial effects limiting mountain height, Nature, 460, 884$887,2009$.

Florineth, D. and Schlüchter, C.: Alpine evidence for atmospheric circulation patterns in Europe during the Last Glacial Maximum, Quaternary Res., 54, 295-308, 2000.

Fox, M., Reverman, R., Herman, F., Fellin, M. G., Sternai, P., and Willett, S. D.: Rock uplift and erosion rate history of the Bergell intrusion from the inversion of low temperature thermochronometric data, Geochemistry, Geophysics, Geosystems, 15, 12351257,2014

Fox, M., Herman, F., Kissling, E., and Willett, S. D.: Rapid exhumation in the Western Alps driven by slab detachment and glacial erosion, Geology, 43, 379-382, 2015.

Glotzbach, C., van der Beek, P., Carcaillet, J., and Delunel, R.: Deciphering the driving forces of erosion rates on millennial to million-year timescales in glacially impacted landscapes: An example from the Western Alps, J. Geophys. Res.-Earth, 118, 1491-1515, 2013.

Granger, D. E. and Schaller, M.: Cosmogenic Nuclides and Erosion at the Watershed Scale, Elements, 10, 369-373, 2014.

Hergarten, S., Wagner, T., and Stüwe, K.: Age and prematurity of the Alps derived from topography, Earth Planet. Sc. Lett., 297, 453-460, 2010.

Herman, F., Seward, D., Valla, P. G., Carter, A., Kohn, B., Willett, S. D., and Ehlers, T. A.: Worldwide acceleration of mountain erosion under a cooling climate, Nature, 504, 423-426, 2013.

Hinderer, M.: Late Quaternary denudation of the Alps, valley and lake fillings and modern river loads, Geodinamica Acta, 14, 231$363,2001$.

Hoffmann, T., Erkens, G., Cohen, K., Houben, P., Seidel, J., and Dikau, R.: Holocene floodplain sediment storage and hillslope erosion within the Rhine catchment, Holocene, 17, 105-118, 2007

Isotta, F. A., Frei, C., Weilguni, V., Tadíc, M. P., Lassègues, P., Rudolf, B., Pavan, V., Cacciamani, C., Antolini, G., Ratto, S. M., Munari, M., Micheletti, S., Bonati, V., Lussana, C., Ronchi, C., Panettieri, E., Marigo, G., and Vertačnik, G.: The climate of daily precipitation in the Alps: development and analysis of a highresolution grid dataset from pan-Alpine rain-gauge data, Int. J. Climatol., 34, 1657-1675, 2014.

Jansen, J. D., Fabel, D., Bishop, P., Xu, S., Schnabel, C., and Codilean, A. T.: Does decreasing paraglacial sediment supply slow knickpoint retreat?, Geology, 39, 543-546, 2011.

Koons, P. O.: On the implications of low spatial correlation of tectonic and climate variables in the western European Alps, Geology, 37, 863-864, 2009.

Koppes, M. N. and Montgomery, D. R.: The relative efficacy of fluvial and glacial erosion over modern to orogenic timescales, Nat. Geosci., 2, 644-647, 2009.

Lal, D.: Cosmic ray labelling of erosion surfaces: in situ nuclide production rates and erosion models, Earth Planet. Sc. Lett., 104, 424-439, 1991.
Legrain, N., Stüwe, K., and Wölfler, A.: Incised relict landscapes in the eastern Alps, Geomorphology, 221, 124-138, 2014.

Legrain, N., Dixon, J., Stüwe, K., von Blanckenburg, F., and Kubik, P.: Post-Miocene landscape rejuvenation at the eastern end of the Alps, Lithosphere, 7, 3-13, 2015.

Mey, J., Scherler, D., Wickert, A. D., Egholm, D. L., Tesauro, M., Schildren, T. F., and Strecker, M. R.: Glacial isostatic uplift of the European Alps, Nat. Comm., 7, 13382, doi:10.1038/ncomms13382, 2016.

Mitchell, S. G. and Humphries, E. E.: Glacial cirques and the relationship between equilibrium line altitudes and mountain range height, Geology, 43, 35-38, 2015.

Molnar, P. and England, P.: Late Cenozoic uplift of mountain ranges and global climate change: chicken or egg?, Nature, 346, 29-34, 1990 .

Montgomery, D. R. and Dietrich, W. E.: A physically based model for the topographic ontrol, Water Resour. Res., 30, 1153-1171, 1994.

Montgomery, D. R. and Korup, O.: Preservation of inner gorges through repeated Alpine glaciations, Nat. Geosci., 4, 62-67, 2011.

Nishiizumi, K., Imamura, M., Caffee, M., Southon, J., Finkel, R., and McAnich, J.: Absolute calibration of ${ }^{10} \mathrm{Be}$ AMS standards, Nucl. Instrum. Meth. B, 258, 403-413, 2007.

Norton, K. P. and Vanacker, V.: Effects of terrain smoothing on topographic shielding correction factors for cosmogenic nuclidederived estimates of basin-averaged denudation rates, Earth Surf. Proc. Land., 34, 145-154, 2009.

Norton, K. P., von Blanckenburg, F., Schlunegger, F., Schwab, M., and Kubik, P. W.: Cosmogenic nuclide-based investigation of spatial erosion and hillslope channel coupling in the transient foreland of the Swiss Alps, Geomorphology, 95, 474-486, 2008.

Norton, K. P., Abbühl, L. M., and Schlunegger, F.: Glacial conditioning as an erosional driving force in the Central Alps, Geology, 38, 655-658, 2010a.

Norton, K. P., von Blanckenburg, F., and Kubik, P. W.: Cosmogenic nuclide-derived rates of diffusive and episodic erosion in the glacially sculpted upper Rhone Valley, Swiss Alps, Earth Surf. Proc. Land., 35, 651-662, 2010b.

Norton, K. P., von Blanckenburg, F., DiBiase, R., Schlunegger, F., and Kubik, P. W.: Cosmogenic ${ }^{10} \mathrm{Be}$-derived denudation rates of the Eastern and Southern European Alps, Int. J. Earth Sci., 100, 1163-1179, 2011.

Ouimet, W. B., Whipple, K. X., and Granger, D. E.: Beyond threshold hillslopes: Channel adjustment to base-level fall in tectonically active mountain ranges, Geology, 37, 579-582, 2009.

Persaud, M. and Pfiffner, O. A.: Active deformation in the eastern Swiss Alps: post-glacial faults, seismicity and surface uplift, Tectonophysics, 385, 59-84, 2004.

Phillips, F. M., Argento, D. C., Balco, G., Caffee, M. W., Clem, J., Dunai, T. J., Finkel, R., Goehring, B., Gosse, J. C., Hudson, A. M., Jull, A. J., Kelly, M., A., Kurz, M., Lal, D., Lifton, N., Marrero, S. M., Nishiizumi, K., Reedy, R. C., Schaefer, J., Stone, J O., Swanson, T., and Zreda, M. G.: The CRONUS-Earth Project: A synthesis, Quaternary Geochronology, 31, 119-154, 2016.

Portenga, E. W. and Bierman, P. R.: Understanding Earth's eroding surface with ${ }^{10} \mathrm{Be}$, GSA Today, 21, 4-10, 2011. 
Qorbani, E., Bianchi, I., and Bokelmann, G.: Slab detachment under the Eastern Alps seen by seismic anisotropy, Earth Planet. Sc. Lett., 409, 96-108, 2015.

Robl, J., Hergarten, S., and Stüwe, K.: Morphological analysis of the drainage system in the Eastern Alps, Tectonophysics, 460, 263-277, 2008

Robl, J., Prasicek, G., Hergarten, S., and Stüwe, K.: Alpine topography in the light of tectonic uplift and glaciation, Global Planet. Change, 127, 34-49, 2015.

Roering, J. J., Kirchner, J. W., and Dietrich, W. E.: Hillslope evolution by nonlinear, slope-dependent transport: Steady state morphology and equilibrium adjustment timescales, J. Geophys. Res.-Sol. Ea., 106, 16499-16513, 2001.

Salcher, B. C., Kober, F., Kissling, E., and Willett, S. D.: Glacial impact on short-wavelength topography and long-lasting effects on the denudation of a deglaciated mountain range, Global Planet. Change, 115, 59-70, 2014.

Savi, S., Norton, K., Picotti, V., Brardinoni, F., Akçar, N., Kubik, P. W., Delunel, R., and Schlunegger, F.: Effects of Effects of sediment mixing on ${ }^{10} \mathrm{Be}$ concentrations in the Zielbach catchment, central-eastern Italian Alps, Quat. Geochronol., 19, 148162, 2014.

Savi, S., Delunel, R., and Schlunegger, F.: Efficiency of frostcracking processes through space and time: An example from the eastern Italian Alps, Geomorphology, 232, 248-260, 2015.

Schaller, M., von Blanckenburg, F., Veldkamp, A., Tebbens, L., Hovius, N., and Kubik, P.: A $30000 \mathrm{yr}$ record of erosion rates from cosmogenic ${ }^{10} \mathrm{Be}$ in Middle European river terraces, Earth Planet. Sc. Lett., 204, 307-320, 2002.

Schlunegger, F. and Norton, K. P.: Water versus ice: The competing roles of modern climate and Pleistocene glacial erosion in the Central Alps of Switzerland, Tectonophysics, 602, 370-381, 2013.

Sternai, P., Herman, F., Champagnac, J.-D., Fox, M., Salcher, B., and Willett, S. D.: Pre-glacial topography of the European Alps, Geology, 40, 1067-1070, 2012.

Thomson, S. N., Brandon, M. T., Tomkin, J. H., Reiners, P. W., Vásquez, C., and Wilson, N. J.: Glaciation as a destructive and constructive control on mountain building, Nature, 467, 313317,2010
Valla, P. G., Schuster, D. L., and van der Beek, P. A.: Significant increase in relief of the European Alps during mid-Pleistocene glaciations, Nat. Geosci., 4, 688-692, 2011.

van der Beek, P. and Bourbon, P.: A quantification of the glacial imprint on relief development in the French western Alps, Geomorphology, 97, 52-72, 2008.

Vernon, A. J., van der Beek, P. A., and Sinclair, H. D.: Spatial correlation between long-term exhumation rates and present-day forcing parameters in the western European Alps, Geology, 37, 859$862,2009$.

von Blanckenburg, F.: The control mechanisms of erosion and weathering at basin scale from cosmogenic nuclides in river sediment, Earth Planet. Sc. Lett., 237, 462-479, 2005.

von Blanckenburg, F., Belshaw, N., and O'Nions, R.: Separation of ${ }^{9} \mathrm{Be}$ and cosmogenic ${ }^{10} \mathrm{Be}$ from environmental materials and SIMS isotope dilution analysis, Chem. Geol., 129, 93-99, 1996.

Wagner, T., Fabel, D., Fiebig, M., Häuselmann, P., Sahy, D., Xu, S., and Stüwe, K.: Young uplift in the non-glaciated parts of the Eastern Alps, Earth Planet. Sc. Lett., 295, 159-169, 2010.

Wittmann, H., von Blanckenburg, F., Kruesmann, T., Norton, K. P., and Kubik, P. W.: Relation between rock uplift and denudation from cosmogenic nuclides in river sediment in the Central Alps of Switzerland, J. Geophys. Res.-Earth, 112, F04010, doi:10.1029/2006JF000729, 2007.

Wittmann, H., Malusà, M. G., Resentini, A., Garzanti, E., and Niedermann, S.: The cosmogenic record of mountain erosion transmitted across a foreland basin: Source-to-sink analysis of in situ ${ }^{10} \mathrm{Be},{ }^{26} \mathrm{Al}$ and ${ }^{21} \mathrm{Ne}$ in sediment of the Po river catchment, Earth Planet. Sc. Lett., 452, 258-271, doi:10.1016/j.epsl.2016.07.017, 2016.

Zhang, W. and Montgomery, D. R.: Digital elevation model grid size, landscape representation, and hydrologic simulations, Water Resour. Res., 30, 1019-1028, 1994. 